\title{
Ways of Coping with Stress and Perceived Social Support Among Mothers of Children with Intellectual Disability
}

\section{Zihinsel Yetersizliği Olan Çocuğa Sahip Annelerde Stresle Başa Çıkma ve Sosyal Destek}

\author{
Huriye Akça Oymak1, (D) Fatma Taş Arslan²
}

${ }^{1}$ Konya Numune Hospital, Konya, Turkey

${ }^{2}$ Selcuk University, Nursing Faculty, Konya, Turkey

\begin{abstract}
Aim: The objective of this study was to determine levels of perceived social support and ways of coping with stress in mothers of children with intellectual disability.

Material and Method: The study was conducted with mothers of children with intellectual disability who were registered in two vocational training centres. The descriptive and cross-sectional study was conducted with 84 mothers of children with intellectual disability. Data were collected the Scale of Ways of Coping with Stress, and with the Multidimensional Scale of Perceived Social Support.

Results: It was found that support from friends, significant others, and total perceived social support increased in mothers of children with intellectual disability, the use of effective ways of coping with stress increased $(p<.05)$. As the children's age increased, the mothers' use of effective methods for stress increased $(p<.05)$. Mothers who had boys and difficulties regarding the future had low levels of perceived social support $(p<.05)$.
\end{abstract}

Conclusion: Social support provided by friends or significant others was important for coping with stress effectively in mothers of children with intellectual disability.

Keywords: Coping, intellectual disability, mothers, social support, stress
Öz

Amaç: Bu çalışmanın amacı, zihinsel yetersizliği olan çocukların annelerinin algıladıkları sosyal destek düzeylerini ve stresle baş etme yollarını belirlemektir.

Gereç ve Yöntem: Çalışma, iki mesleki eğitim merkezine kayıtlı zihinsel engelli çocukların anneleriyle gerçekleştirilmiştir. Tanımlayıc ve kesitsel çalışma, zihinsel yetersizliği olan 84 çocuğun annesi ile yapılmışıı. Veriler, Stresle Başa Çıkma Yolları Ölçeği ve Çok Boyutlu Algılanan Sosyal Destek Ölçeği ile toplanmışıı.

Bulgular: Zihinsel yetersizliği olan çocukların annelerinde arkadaşların desteği, diğer önemli kişiler ve algılanan toplam sosyal destek arttıkça, stresle başa çıkmanın etkili yollarının kullanımının arttığı bulunmuştur $(p<, 05)$. Çocukların yaşı arttıkça, annelerin stres için etkili yöntemler kullanımı artmıştır $(p<, 05)$. Erkek çocukları ve geleceğe ilişkin zorlukları olan annelerin algılanan sosyal destek düzeyleri düşüktü $(p<, 05)$.

Sonuç: Zihinsel engelli çocukların annelerine arkadaşlar veya önemli kişiler tarafından sağlanan sosyal destek, stresle etkin bir şekilde başa çıkmak için önemliydi.

Anahtar Kelimeler: Başetme, zihinsel yetersizlik, anne, sosyal destek, stres 


\section{INTRODUCTION}

Intellectual disability is a condition that is observed in mental functions and adaptive behaviours and characterised by a significant levels of limitation and cognitive, social, and practical adaptive skills. ${ }^{[1]}$ According to the World Report on Disability, more than 1 billion people, which corresponds to approximately $15 \%$ of the world's population, live with some type of disability, $3 \%$ of which are reported as intellectual disability. ${ }^{[2]}$ The rate of disability in the Turkish population is $12.29 \%$, about 8.5 million people; $0.48 \%$ of this group comprises individuals with intellectual disability and $1 \%$ of these are aged $0-19$ years. ${ }^{[3]}$

In cases of disability, children especially and their families may face many different situations in every area of life. Having a child with intellectual disability imposes an emotional burden on families and also causes them to experience physical, social, and economic problems. Families that have children with intellectual disability have higher levels of depression, deep sadness, loneliness, anger, anxiety ${ }^{[4]}$ and stress. ${ }^{[5]}$ Previous studies reported that families have difficulties in reorganising their live and experience stress in relation to intellectual disability ${ }^{[6-8]}$ Mothers' stress levels are affected by the age and sex of the child with intellectual disability, diagnosis duration, level of intellectual disability, educational level of the mother, lack of knowledge, failure to fulfil roles within family, socioeconomic level of family, cultural structure, care burden, strain in marital relationships, the decrease in participation in social activities, attitude of society toward the child with intellectual disability, and whether the mother receives social support. ${ }^{[9-12]}$

When examining the literature, it is seen that social support conditions of parents of children with intellectual disability contribute to effective coping with stress. ${ }^{[12,13]}$ Social support is generally defined as a financial or moral assistance provided to a person by their closest ones in a stressful situation. It is accepted that social support is necessary lifelong, covers the sense of belonging, and provides a positive interaction. ${ }^{[14]}$ The stress experienced by parents of children with intellectual disability is mainly associated with lack of support from their circle. ${ }^{[13]}$ It has been determined that mothers receiving support from their social circle are more successful at coping with stress. ${ }^{[13,15]}$ In addition, other factors may be effective in dealing with stress. Under stressful conditions, individuals show a tendency to approach someone in order to cope with this situation. Social, emotional or financial support provided in this process comforts the individual. ${ }^{[6,13,15]}$ It is known that social support can prevent the development of stress, change the perception of stressful events, support the individual in case of difficulty, and affect the ways of coping with stress. ${ }^{[16,17]}$ Social support affects the behaviours and development of children with disabilities and their parents, and plays a preventive and development-supportive role by increasing their competence. ${ }^{[18]}$
Among healthcare professionals providing care to individuals with intellectual disability, nurses make important interventions in the prevention, early diagnosis of intellectual disability, and maintenance of family-centred care in primary, secondary, and tertiary healthcare services. It is thought that this study will guide specialists who provide service in this area, help nurses to plan training and counselling practices for mothers, and contribute to the nursing literature. In addition, it is considered important to evaluate the perception of stress and social support of mothers with children with intellectual disabilities in different groups (region, education, etc.). The aim of this study was to determine the ways of coping with stress and perceived social support levels of mothers of children with intellectual disability and to investigate associated factors. The research questions were as follows:

1.Does coping with stress indicate any difference in sociodemographic variables (marital and educational status; perception of income; number of children; gender; level of disability; and experiences of mothers)?

2. Does perceived social support indicate any difference in sociodemographic variables (marital and educational status; perception of income; number of children; gender; level of disability; and experiences of mothers)?

3. Is there any correlation between perceived social support and coping with stress?

4. What is the predictive power of the perceived social support score on scores of effective coping?

\section{MATERIAL AND METHOD}

\section{Design and sample}

The descriptive and cross-sectional study was conducted at two vocational training centres affiliated (permitted) with the Provincial Directorate for National Education in a large city of Turkey between 10 February 2017 and 30 April 2017. A total of 267 intellectual disability children enrolled in these centers were receiving education. The sample of the study consisted of the mothers of children with intellectual disability. The study was completed with 84 mothers who agree to participate in the study, and $32 \%$ of the sample could be reached. Mothers who can understand and speak Turkish was inclusion from of the study. Mothers with more than one disabled child were excluded from the study.

\section{Measures}

Data were collected using an information form on the sociodemographic characteristics (mothers and children age, marital status, educational status, perception income, level of disability (it was obtained from the file in school etc.) of participants' experiences of intellectual disability features of their children (Child care, Concern about the future of their children, failure to fulfill life-related roles, the lack of social life ect.) , The Scale of Ways of Coping with Stress (SWCS), and the Multidimensional Scale of Perceived Social Support (MSPSS). 
The SWCS was developed by Folkman and Lazarus (1980). The Turkish adaptation and validation of SWCS was conducted by Şahin and Durak (1995). The original version of SWCS consisted of 66 items and the number of items was reduced to 30 in Şahin and Durak's (1995) version. The SWCS is a 4-point Likert- type scale ranging from 1 (Not appropriate) to 4 (Very appropriate). In the Turkish adaptation and validation of SWCS, factor analysis, comparisons of measurement-correlating validity, and counter groups and validity for the SWCS were performed and Cronbach's alpha reliability coefficients of the subscales were found between 0.45 and 0.80 . According to the factor analysis, it revealed five ways of coping with stress: optimistic approach, self-confident approach, hopelessness approach, submissive approach, and seeking social support. The scale consists of two groups. One is the effective coping ways (ECWs), which contains the optimistic approach, selfconfident approach, and seeking social support. The other group is the ineffective coping ways (ICWs), which includes the hopelessness approach and submissive approach. In the SWCS, each group is independent and assessed separately. Higher scores signify the use of the approach to cope with stress. ${ }^{[20]}$ In the present study, the Cronbach's alpha coefficient for the SWCS scale was 0.87 .

The MSPSS was developed by Zimet, Dahlem, Zimet, and Farley (1988). The MSPSS is a 12 short-item Likert-type scale. The scale has 3 subscales (family, friends, and significant other) including 4 items in each, and each item is scored between 1 and 7 . Scores range from 12 to 84 . The lowest and the highest scores for the subscales are 4 and 28, respectively. Higher total scores indicate greater perceived social support. The Turkish adaptation and validation of MSPSS were conducted by Eker et al. in 2001. The Turkish version also showed good psychometric properties and its Cronbach's alpha coefficient was $0.89 .^{[14]}$ In the present study, the Cronbach's alpha coefficient for the MSPSS scale was 0.88 .

\section{Procedure}

Mothers who met the inclusion criteria for the study were informed about the topic and the purpose of the research, and mothers who agreed to participate in the study were asked to read and sign an informed consent form. Those mothers who agreed to participate in the study also completed the information form, SWCS, and MSPSS during a face-to-face interview with a researcher in the interview room. The forms took roughly 15 to 20 minutes to complete.

\section{Ethical considerations}

Before starting the study, approval was granted by the Selcuk University Health Sciences Faculty Noninterventional Clinical Research Ethics Committee (decision no: 2017/14). and written permission was obtained from the institution in which the study was carried out. Mothers who accepted to participate in the study were informed that the decision about participating in the study was completely their own, that the collected information will be confidential, and that the data will be used within the scope of the research. Written informed consent was obtained from the participants.

\section{Data analysis}

The Statistical Package for the Social Sciences version 22.0 was used. The suitability of the data to normal distribution was done by Kolmogorov Smirnov test and it was found to show normal distribution. Data are represented as number, percentages, mean, and standard deviation, and the comparisons between the groups were performed using Student's $t$ and F-tests. The correlation between the mothers' sociodemographic characteristics and perceived social support and coping with stress was evaluated using Pearson's correlation analysis. In order to determine the effect of perceived social support from family, friends, and significant other on the ECWs, linear regression analysis was performed. The significance level was 0.05 for all tests, and $95 \%$ confidence intervals were also calculated.

\section{RESULTS}

The mean age of the mothers was $45.04 \pm 7.41$ and $77.4 \%$ were married. It was found that $71.4 \%$ of the mothers had average income, and $80.9 \%$ were primary school graduates. It was found that $71.4 \%$ of the mothers had average income, $80.9 \%$ primary school graduates, and $58.3 \%$ had more than three children. The mean age of the children was $16.88 \pm 2.88,57.1 \%$ were male, and $48.8 \%$ were mildly disabled (Table 1 ).

\begin{tabular}{|c|c|c|}
\hline Characteristics & Number & Percentage \\
\hline Mean age of the mothers (years) & Mean (SD) & $45.04(7.41)$ \\
\hline Mean age of the children (years) & Mean (SD) & $16.88(2.88)$ \\
\hline \multicolumn{3}{|l|}{ Marital status } \\
\hline Married & 65 & 77.4 \\
\hline Unmarried & 19 & 22.6 \\
\hline \multicolumn{3}{|l|}{ Educational status } \\
\hline Primary school & 68 & 80.9 \\
\hline Secondary school and higher & 16 & 19.1 \\
\hline \multicolumn{3}{|l|}{ Perception of income } \\
\hline Low & 24 & 28.6 \\
\hline Middle & 60 & 71.4 \\
\hline \multicolumn{3}{|l|}{ Number of children } \\
\hline 1 & 7 & 8.4 \\
\hline 2 & 28 & 33.3 \\
\hline$\geq 3$ & 49 & 58.3 \\
\hline \multicolumn{3}{|l|}{ Sex } \\
\hline Female & 36 & 42.9 \\
\hline Male & 48 & 57.1 \\
\hline \multicolumn{3}{|l|}{ Level of disability } \\
\hline Mild & 41 & 48.8 \\
\hline Moderate & 30 & 35.7 \\
\hline Severe/profound & 13 & 15.5 \\
\hline
\end{tabular}


Education and marital status, perception of income, number of children, and level of disability had no significant difference with MSPSS and ECW scores and ICW scores ( $p>05$ ). Mothers who had girls had significantly higher MSPSS scores $(p<.05)$ (Table 2). Mothers who experienced difficulties regarding the future of the child had significantly lower MSPSS scores $(p<.05)$ (Table 3).

\begin{tabular}{|c|c|c|c|c|}
\hline & Number & $\begin{array}{l}\text { Total } \\
\text { MSPSS }\end{array}$ & $\begin{array}{c}\text { Effective } \\
\text { Coping Ways }\end{array}$ & $\begin{array}{c}\text { Ineffective } \\
\text { Coping Ways }\end{array}$ \\
\hline \multicolumn{5}{|l|}{ Marital status } \\
\hline Married & 65 & $63.73 \pm 18.15$ & $32.63 \pm 7.83$ & $19.36 \pm 9.91$ \\
\hline Unmarried & 19 & $58.57 \pm 21.29$ & $30.73 \pm 10.37$ & $19.78 \pm 10.46$ \\
\hline$t / p$ & & $0.959 / .298$ & $0.858 / .393$ & $-0.161 / .873$ \\
\hline \multicolumn{5}{|l|}{ Educational status } \\
\hline Primary school & 68 & $63.91 \pm 18.38$ & $32.29 \pm 8.57$ & $19.66 \pm 9.70$ \\
\hline $\begin{array}{l}\text { Secondary } \\
\text { school and } \\
\text { higher }\end{array}$ & 16 & $56.87 \pm 20.60$ & $31.81 \pm 8.15$ & $18.62 \pm 11.36$ \\
\hline$t / p$ & & $1.254 / .182$ & $0.204 / .839$ & $0.337 / .711$ \\
\hline \multicolumn{5}{|c|}{ Perception of income } \\
\hline Low & & $60.08 \pm 23.13$ & $29.66 \pm 9.10$ & $19.04 \pm 10.02$ \\
\hline Middle & 24 & $63.56 \pm 17.04$ & $33.21 \pm 8.02$ & $19.63 \pm 10.03$ \\
\hline$t / p$ & & $-0.761 / .449$ & $-1.668 / .082$ & $-0.244 / .808$ \\
\hline \multicolumn{5}{|l|}{ Number of children } \\
\hline 1 & 7 & $68.71 \pm 23.44$ & $34.28 \pm 11.75$ & $23.57 \pm 15.96$ \\
\hline 2 & 28 & $61.71 \pm 20.02$ & $32.17 \pm 8.47$ & $18.92 \pm 10.85$ \\
\hline$\geq 3$ & 49 & $62.18 \pm 17.81$ & $31.91 \pm 8.05$ & $19.18 \pm 8.44$ \\
\hline$F / p$ & & $0.403 / .670$ & $0.236 / .790$ & $0.647 / .526$ \\
\hline \multicolumn{5}{|l|}{ Sex } \\
\hline Female & 36 & $67.63 \pm 16.05$ & $33.97 \pm 7.23$ & $21.05 \pm 11.08$ \\
\hline Male & 48 & $58.77 \pm 20.11$ & $30.87 \pm 9.10$ & $18.27 \pm 9.00$ \\
\hline$t / p$ & & $2.175 / .032$ & $1.737 / .097$ & $1.233 / .208$ \\
\hline \multicolumn{5}{|l|}{ Level of disability } \\
\hline Mild & 41 & $61.14 \pm 19.41$ & $31.09 \pm 8.56$ & $18.63 \pm 9.66$ \\
\hline Moderate & 30 & $65.83 \pm 16.64$ & $32.80 \pm 8.82$ & $20.25 \pm 9.99$ \\
\hline $\begin{array}{l}\text { Severe/ } \\
\text { profound }\end{array}$ & 13 & $57.50 \pm 22.19$ & $34.41 \pm 6.93$ & $20.25 \pm 11.56$ \\
\hline$F / p$ & & 1.197 / .308 & $0.839 / .436$ & $0.272 / .762$ \\
\hline
\end{tabular}

It was determined that as the age level increased, the total score of the ECWs $(r=0.249, p<.05)$ increased. As total perceived social support $(r=0.244, p<.05)$ and friends $(r=0.225, p<.05)$, and significant other $(r=0.256, p<.05)$ increased, the use of the ECWs increased (Table 4).

Based on the regression analysis, social support from friends and significant others were determined to be effective in the use of the ECWs $(p<.05)$. Additionally, it has been established that the determining factors explained the change as $5 \%$ of friends and $6 \%$ of others in the ECWs. (Table 5).
Table 3. Comparison of the scores of coping ways with stress and perceived social support regarding difficulty experiences of the mothers $(n=84)$

\begin{tabular}{lcccc}
$\begin{array}{l}\text { Difficulty } \\
\text { experiences }\end{array}$ & Number & Total MSPSS & $\begin{array}{c}\text { Effective } \\
\text { Coping Ways }\end{array}$ & $\begin{array}{c}\text { Ineffective } \\
\text { Coping Ways }\end{array}$ \\
\hline Child care & & & & \\
Yes & 26 & $60.88 \pm 18.07$ & $30.34 \pm 8.42$ & $20.03 \pm 8.34$ \\
No & 58 & $63.32 \pm 19.36$ & $33.03 \pm 8.39$ & $19.20 \pm 10.68$ \\
t/p & & $-0.560 / .587$ & $-1.354 / .179$ & $0.386 / .726$ \\
\hline
\end{tabular}

Economic Status

$\begin{array}{ccccc}\text { Yes } & 24 & 62.91 \pm 22.39 & 31.00 \pm 8.20 & 19.16 \pm 9.19 \\ \text { No } & 60 & 62.43 \pm 17.52 & 32.68 \pm 8.56 & 19.58 \pm 10.34 \\ & & 0.095 / .916 & -0.839 / .413 & -0.181 / 864\end{array}$

$\begin{array}{llll}\mathrm{t} / \mathrm{p} & 0.095 / .916 & -0.839 / .413 & -0.181 / .864\end{array}$

Concern about the future of their children

$\begin{array}{ccccc}\text { Yes } & 49 & 58.73 \pm 15.96 & 30.75 \pm 8.48 & 18.02 \pm 8.38 \\ \text { No } & 35 & 67.94 \pm 21.48 & 34.22 \pm 8.07 & 21.48 \pm 11.68 \\ \mathrm{t} / \mathrm{p} & & -2.225 / .027 & -1.903 / .063 & -1.583 / .117\end{array}$

Failure to fulfill life-related roles

$\begin{array}{ccccc}\text { Yes } & 18 & 58.50 \pm 17.24 & 28.88 \pm 6.83 & 18.22 \pm 5.26 \\ \text { No } & 66 & 63.68 \pm 19.30 & 33.10 \pm 8.66 & 19.80 \pm 10.92 \\ t / p & & -1.100 / .305 & -2.183 / .060 & -0.593 / .555\end{array}$

The lack of social life

\begin{tabular}{lllll} 
Yes & 19 & $62.47 \pm 15.04$ & $32.10 \pm 7.31$ & $22.63 \pm 8.88$ \\
No & 65 & $62.60 \pm 19.99$ & $32.23 \pm 8.80$ & $18.53 \pm 10.15$ \\
t/p & & $-0.030 / .980$ & $-0.063 / .955$ & $1.708 / .116$ \\
\hline Discrimination & & & & \\
Yes & 23 & $60.60 \pm 19.12$ & $33.00 \pm 7.93$ & $19.82 \pm 10.07$ \\
No & 61 & $63.31 \pm 18.92$ & $31.90 \pm 8.67$ & $19.32 \pm 10.02$ \\
t/p & & $0.582 / .562$ & $0.551 / .598$ & $0.202 / .840$ \\
\hline
\end{tabular}

Abbreviation: MSPSS, Multidimensional Scale of Perceived Social Support.

Table 4. The correlation between mothers' and children's age, and coping with stress and perceived social support

$\begin{array}{lrrrrrr} & \text { ECWs } & \text { ICWs } & \text { Family } & \text { Friends } & \begin{array}{c}\text { Significant } \\ \text { Other }\end{array} & \text { Total } \\ \begin{array}{lrrrrr}\text { Mother's } \\ \text { age }\end{array} & -0.007 & -0.009 & 0.045 & -0.004 & 0.072 & 0.048 \\ \text { Child's age } & 0.249^{*} & 0.041 & 0.032 & 0.113 & 0.181 & 0.144 \\ \text { Family } & 0.196 & 0.126 & & & & \\ \begin{array}{l}\text { Friends } \\ \text { Significant }\end{array} & 0.225^{*} & 0.161 & & & & \\ \text { Other } & 0.256^{*} & 0.232^{*} & & & & \\ \text { Total } & 0.284^{*} & 0.221^{*} & & & & \end{array}$

Abbreviations: ECWs, effective coping ways with stress; ICWs, ineffective coping ways with stress. ${ }^{*} p<.05$.

Table 5. The effect of scores of perceived social support on scores of effective coping ways with stress among mothers

\begin{tabular}{lcccc} 
& Beta & $\mathbf{t}$ & $\mathbf{p}$ & $\mathbf{9 5 \%} \mathbf{C l}$ \\
\hline Family & 0.252 & 1.806 & .075 & -0.026 to 0.529 \\
Friend & 0.236 & 2.090 & .040 & 0.011 to 0.461 \\
Significant other & 0.244 & 2.401 & .019 & 0.042 to 0.446 \\
& & $\mathrm{R}=.284$ & $\mathrm{R} 2=.081$ & $\mathrm{p}=0.009$ \\
\hline Cl, confidence interval. & & & &
\end{tabular}




\section{DISCUSSION}

It is important to determine the effect of social support and other factors in mothers of children with intellectual disability to cope with stress. In the present study, it was determined that as social support from friends and significant others increased, ECWs were used more frequently. Different theories have been suggested regarding the positive effects of social support. It was reported that social support decreased weakness against both internal and external stress factors and was useful in coping with stress. ${ }^{[16,17,22]}$ Also, it has been found that the needs of social support are significant ${ }^{[6]}$ and greater. ${ }^{[9]}$ among mothers of children with intellectual disability, and those receiving social support have better use of effective ways of coping with stress. ${ }^{[12]}$

In the literature, it was revealed that an increase in mothers' perceived social support decreased their levels of stress. ${ }^{[13,16,17]}$ In that study, as children's age increased, mothers' use of effective ways of coping with stress increased. On the other hand, in the literature it is reported that as the age of children with intellectual disability decreases, mothers' use of effective ways of coping with stress increased ${ }^{[12]}$ and another study stated that children's age was effective on parents' stress. ${ }^{[23]}$ It is thought that mothers' use of effective coping ways with stress increases because problems experienced in this process can be solved through experience.

In the present study, it was observed that the mothers of girls had higher social support than those of boys; however, their use of effective and ineffective coping mechanisms was similar. In Turkey, mothers are generally responsible for all housework, and girls help their mothers more than boys while fulfilling these responsibilities. This result may be associated with the fact that mothers are closer to their girls and feel their support more. In the current study, the use of social support and effective and ineffective coping methods by married and single mothers showed no difference, which is thought to be associated with the culture and lifestyles of families in Turkey. In Turkey, women often continue to live with their parents after divorce, especially in traditional families and women not working.

In our study, there was no difference between the educational status of the mothers and their use of social support and effective and ineffective coping methods. However, in the literature it is found that as educational level increases, the level of perceived social support increases ${ }^{[16,24]}$ and as mothers' educational level decreases, they use ineffective coping methods for stress. ${ }^{[6,12,15]}$ Unlike the literature, this result may be associated with the fact that the mothers in the present study did not have a high level of education.

There was no difference between the employment and income status of mothers in the present study and their use of social support and effective and ineffective coping ways. In similar studies, no difference was found between income status and social support and coping with stress. ${ }^{[15,25]}$ In some studies, however, it has been reported that mothers with a lower income and are unemployed used ineffective ways of coping with stress. ${ }^{[6,12]}$ and low economic condition increased stress. ${ }^{[13]}$ Mothers' employment status is a condition that supports the increase in income. In Turkey, financial support is provided to To individuals with disability and their families via public and private institutions. In this context, it is thought that the disabled children's families have greater emotional and social problems than financial problems.

The number of children and the level of intellectual disability and the use of social support and effective and ineffective coping methods showed no difference in our study. The number of children could either ease or increase the burden of families. In Turkey, siblings assist in the care of sick or younger children, which is a cultural condition. In the literature, it is seen that the increase in the level of intellectual disability increases the care burden of families ${ }^{[26,27]}$; and it is thought that the increase of the care burden changes the ability to cope with stress. On the other hand, in a study it was reported that the level of disability was not effective on the stress of parents. ${ }^{[23]}$ The present study, however, revealed that the level of intellectual disability did not change mothers' perceived social support and their use of effective and ineffective coping methods for stress. This result may have resulted from the characteristics of this sample. However, there is variability in the extent to which mothers are affected by behavioral and emotional problems

We observed that difficulties experienced by mothers of children with intellectual disabilities were multidimensional. Similar to our data, in the literature, it is reported that the difficulties experienced by mothers are collected under titles such as child's future, child's care, failure to fulfill life-related roles (wife, mother), having no social life, marital conflicts, and social exclusion. ${ }^{[4,5,15,28]}$ It is stated that these difficulties experienced by mothers increase their stress experience. ${ }^{[4]}$ In our study, the mothers who experienced concern about the future of their children had lower social support. Similarly, it was determined in a study that those experiencing stress regarding their child's future had low levels of social support. ${ }^{[29]}$ Both the literature and the present study have revealed that parents experiencing no concern about the future of their children had high levels of perceived social support. It can be asserted that mothers with a high level of social support experience this anxiety less. It was found that social support perceived in mothers of children with intellectual and developmental disabilities functions as a protective factor. ${ }^{[30]}$

In the present study, it was observed that social support from friends and significant others increased the use of effective coping mechanisms. In the literature, it is reported that perceived social support was important for effective coping. ${ }^{[12,13]}$ Similarly, it has been reported that social support increased the use of effective coping. ${ }^{[16,17,22,27]}$ Researchers assessing the relationship between coping with stress and social support agree that social support plays a crucial role in coping. ${ }^{[9,13]}$ 


\section{Limitation}

The study was performed in two centers. The number of samples could be higher.

\section{CONCLUSIONS}

We found that support from friends, significant others, and total perceived social support increased in mothers of children with intellectual disability, their effective use of ways of coping with stress increased. It was observed that as mothers' perceived social support and the child's age increased, their use of effective coping methods increased and those who had boys and problems regarding their future had low levels of perceived social support. Whether a families' way of coping with stress caused by having a child with an intellectual disability was effective depended on the support received from social circles. This result makes us think that as long as families are supported, they can cope with their difficulties more easily. It is considered that nurses and healthcare professionals working in this area play an important role for families, especially for mothers, in coping with the difficulties of having children with intellectual disability. Nurses' roles such as caregiver, trainer, counselor, and guidance provider take an important place in primary, secondary, and tertiary healthcare services. It would be useful for nurses to guide mothers of children with intellectual disability to strengthen their social support systems to effectively cope with stress.

Studies with larger sample groups from different regions in Turkey are required to investigate the relationship between regional and cultural differences with effective coping methods and social support. Studies with families with different education and income level are needed to compare the results. Structured programs should be prepared and experimental studies conducted to increase the effective ways of coping with stress or social support of families of children with intellectual disability.

\section{ETHICAL DECLARATIONS}

Ethics Committee Approval: Before starting the study, approval was granted by the Selcuk University Health Sciences Faculty Noninterventional Clinical Research Ethics Committee (decision no: 2017/14).

Informed Consent: All patients signed the free and informed consent form.

Referee Evaluation Process: Externally peer-reviewed.

Conflict of Interest Statement: The authors have no conflicts of interest to declare.

Financial Disclosure: The authors declared that this study has received no financial support.

Author Contributions: All of the authors declare that they have all participated in the design, execution, and analysis of the paper, and that they have approved the final version.
Acknowledgements: This study was presented as a poster at the 5th International and 16th National Nursing Congress, 5-8 November 2017, Ankara, Turkey. We gratefully thank all the mothers and the team of the translation company.

\section{REFERENCES}

1. AAIDD. Intellectual Disability: Definition, Classification, and Systems of Supports (11th ed.). Washington DC. 2010.

2. WHO. Disability. (2017) Available from: http://www.who.int/topics/ disabilities/en/

3. DIE. Türkiye Ozürlüler Araştirması. Devlet İstatistik Enstitüsü Matbaası: Ankara; 2002.

4. Sen E, Yurtsever S. Difficulties experienced by families with disabled children. JSPN 2007;12(4):238-52.

5. Bawalsah JA. Stress and coping strategies in parents of children with physical, mental, and hearing disabilities in jordan. International Journal of Education 2016;8(1):1-22.

6. Dicle A. Otistik çocuğa sahip ebeveynlerin başa çıkma tutumları ve duygu kontrol durumları arasındaki ilişki. SSSJournal 2017;(3):955-65.

7. Olsson I, Roll-Pettersson L. 'No no, you cannot say that!'Perceptions and experiences of parents of preschool children with intellectual disabilities in Sweden. Eur J Spec Needs Educ 2012;27(1):69-80.

8. Durualp E, Kocabas K, Arslan A, Ozaydin K. The examination of the needs and stress levels of the parents of handicapped children in terms of some variables. US-China Educ Rev B 2011;2:260-72.

9. Kaytez N, Durualp E, Kadan G. Engelli çocuğu olan ailelerin gereksinimlerinin ve stres düzeylerinin incelenmesi. Eğitim ve Öğretim Araştırmaları Derg 2015;4(1):197-214.

10. DeLambo D, Chung W, Huang W. Stress and age: A comparison of Asian American and non-Asian American parents of children with developmental disabilities. J Dev Phys Dısabıl 2011;23(2):129-41.

11. Putnick DL, Bornstein MH, Hendricks C, Painter KM, Suwalsky JT, Collins WA. Stability, continuity, and similarity of parenting stress in European American mothers and fathers across their child's transition to adolescence. Parenting: Science and Practice 2010;10(1):60-77.

12. Gülşen B, Özer FG. Engelli çocuğa sahip ailelerin stresle baş etme durumları. TAF Prev Med Bull 2009;8(5):413-20.

13. Patton KA, Ware R, McPherson L, Emerson E, Lennox N. Parent-related stress of male and female carers of adolescents with intellectual disabilities and carers of children within the general population: a crosssectional comparison. J Appl Res Intellect Disabil 2018;31(1):51-61.

14. Eker D, Arkar H, Yaldiz H. Çok Boyutlu Algılanan Sosyal Destek Ölçeği'nin Gözden geçirilmiş formunun faktör yapısı, geçerlik ve güvenirliği.Turk Psikiyatri Derg 2001;12:14-25.

15. Ayyıldız T, Şener DK, Kulakçı H, Veren F. Zihinsel engelli çocuğa sahip annelerin stresle baş etme yöntemlerinin değerlendirilmesi. Ankara Sağlık Hizmetleri Derg 2013;11(2):1-12.

16. Coşkun Y, Akkaş G. Engelli çocuğu olan annelerin sürekli kaygı düzeyleri ile sosyal destek algıları arasındaki ilişki. Ahi Evran Üniversitesi Kırşehir Eğitim Fakültesi Derg 2009;10(1):213-27.

17. Ersoy Ö, Çürük N. Özel gereksinimli çocuğa sahip annelerde sosyal desteğin önemi. Aile ve Toplum 2009;11(5):104-10.

18. Kaner S. Aile Katılımı ve İşbirliği. In: Sucuoğlu B, editor. Zihin Engelliler ve Eğitimleri. Ankara: Kok Yayıncılık; 2009. p. 352-405.

19. Folkman S, Lazarus RS. An analysis of coping in a middle-aged community sample. J Health Soc Behav 1980;21(3):219-39.

20. Şahin N, Durak A. Stresle başaçıkma tarzları ölçeği: üniversite öğrencileri için uyarlanması. Türk Psikoloji Derg 1995;10(34):56-73.

21. Zimet GD, Dahlem NW, Zimet SG, Farley GK. The multidimensional scale of perceived social support. J Pers Assess 1988;52(1):30-41. 
22. Cavkaytar A, Batu S, Cetin OB. Perspectives of Turkish mothers on having a child with developmental disabilities. Int J Spec Educ 2008;23(2):101-9.

23. Khamis V. Psychological distress among parents of children with mental retardation in the United Arab Emirates. Soc Sci Med 2007;64(4):850-7.

24. Park SY, Glidden LM, Shin JY. Structural and functional aspects of social support for mothers of children with and without cognitive delays in Vietnam. J Appl Res Intellect Disabil 2010;23(1):38-51.

25. Karpat D, Girli A. Yaygın gelisimsel bozukluk tanılı cocukların annebabalarının yas tepkilerinin, evlilik uyumlarının ve sosyal destek algılarının incelenmesi. Ankara Üniversitesi Eğitim Bilimleri Fakültesi Özel Eğitim Derg 2012;13(02):69-85.

26. Turan Gürhopur FD, İşler Dalgiç A. Zihinsel Yetersiz Çocuğu Olan Ebeveynlerde Aile Yükü. J Psychiatric Nursing/Psikiyatri Hemsireleri Derg 2017;8(1):9-16.

27. Sivrikaya T, Tekinarslan iç. Zihinsel yetersizliği olan çocuğa sahip annelerde stres, sosyal destek ve aile yükü. Ankara Üniversitesi Eğitim Bilimleri Fakültesi Özel Eğitim Derg 2013;14(2):17-29.

28. Wang P, Michaels CA, Day MS. Stresses and coping strategies of Chinese families with children with autism and other developmental disabilities. J Autism Dev Disord 2011;41(6):783-95.

29. Karadağ G. Engelli çocuğa sahip annelerin yaşadıkları güçlükler ile aileden algıladıkları sosyal destek ve umutsuzluk düzeyleri. TAF Prev Med Bull 2009;8(4):315-22.

30. Halstead EJ, Griffith GM, Hastings RP. Social support, coping, and positive perceptions as potential protective factors for the well-being of mothers of children with intellectual and developmental disabilities. Int J Dev Disabil 2018;64(4-5):288-96. 